\title{
Chédiak-Higashi syndrome with novel gene mutation
}

\author{
Mostafa M Helmi, ${ }^{1}$ Maysa Saleh, ${ }^{1}$ Bushra Yacop, ${ }^{1}$ Doaa ElSawy ${ }^{2}$
}

${ }^{1}$ Pediatrics department, Latifa Hospital, Dubai Health Authority, Dubai, UAE ${ }^{2}$ Haematolgy \& Transfusion unit, Pathology Department, Latifa Hospital, Dubai Health Authority, Dubai, UAE

\section{Correspondence to}

Dr Maysa Saleh, maytawsal@ yahoo.com

Accepted 23 January 2017

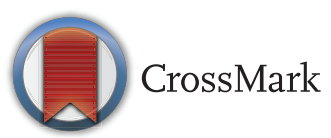

To cite: Helmi MM, Saleh M, Yacop B, et al. BMJ Case Rep Published online: [please include Day Month Year] doi:10.1136/ bcr-2016-216628

\section{SUMMARY}

Chédiak-Higashi syndrome (CHS) is a rare disorder of immune deficiency with autosomal recessive inheritance. Over the past 20 years, $\sim 500$ cases were published worldwide. The mean age of onset is 5-6 years. We report here a case of CHS in a boy aged $2 \frac{1}{2}$ years who presented to us with pneumonia which turned to be Chédiak-Higashi syndrome with a novel variant, not previously described in the literature, which is caused by mutations in the CHS1 gene.This case is reported for its novel mutation, and the absence of the accelerated phase until now. Awareness, early recognition and management of this condition may prevent the preterm morbidity associated with this case.

\section{BACKGROUND}

Chédiak-Higashi syndrome (CHS) is a rare autosomal recessive immune disease characterised by oculocutaneous albinism, a predisposition for infections, coagulopathies, neurological dysfunction and large granules in many cell types. ${ }^{1}$ CHS is caused by homozygous or compound heterozygous mutations of the CHS1 gene. This gene, which was originally called LYST, a lysosomal trafficking regulatory gene, is mapped to chromosomal locus $1 \mathrm{q} 42.1-\mathrm{q} 42.2 .^{2}{ }^{3}$

The syndrome is categorised into classic and atypical (mild) forms. Children with the classic form of the disease are at risk for developing the accelerated phase. The accelerated phase of CHS, termed haemophagocytic lymphohistiocytosis, ${ }^{4}$ presented in almost $85 \%$ of patients. This phase is a form of lymphoproliferative infiltration of the bone marrow and reticuloendothelial system. Nevertheless, in the atypical form, the accelerated phase has a later onset, a history of unusual or severe infections is absent and neurological impairment is more prominent.

The diagnosis of CHS is usually made by the presence of 'giant granules' in microscopic analysis of white cell counts.

In this report, our patient presented with an inconclusive clinical manifestation of CHS. He was diagnosed by the presence of large granules in the cytoplasm of neutrophils, eosinophils and in a few lymphocytes in blood film. The genotype of our patient identified the causative mutation in the CHS1 gene. We found a homozygous c.6159_6160del (p.Met2053Ilefs*31) variant which is most likely a disease-causing mutation. Yet it was not reported previously. Until now, $<75$ mutations have been described in this syndrome (table 1).

\section{CASE PRESENTATION}

A boy aged $2^{1 / 2}$ years was admitted with right-sided pneumonia, which did not improve on antibiotics.
Prior to admission, the child had a history of fever and poor appetite of 2 weeks duration. He had no cough, sweating, vomiting, diarrhoea or urinary symptoms. The child had a history of recurrent wheezing which was managed by nebulised bronchodilators. Moreover, there was a history of skin discolouration and weight loss for the past 8 months. The child was under treatment for infantile eczema. One year back, he had scalp abscess, which was resolved by oral antibiotics. The child was born term by Lower segment Caesarean section (LSCS) due to previous LSCS and Placenta Previa. His mother had gestational diabetes. He had an uneventful prenatal, natal and postnatal history. His birth weight was $3 \mathrm{~kg}$. He was born to consanguineous parents; his parents are cousins. He has two healthy elder brothers and a sister. His vaccination schedule was up to date. There was a history of contact with a caregiver who had old treated tuberculosis.

On examination, he was afebrile with normal vital signs. His general condition was good apart from pallor with good nutritional status. No lymph nodes were palpable. He has greyish short sparse hair. There was a hyperpigmented area at the forehead with other hypopigmented patches on the face, behind the ear (figure 1A), at the trunk, the scapular area (figure 1B), the dorsum of the hand (figure 1C), and extremities, especially the dorsum of the foot and upper inner thighs (figure 1D). The scrotum, flexural areas and creases were spared. There was no joint swelling or tenderness. His weight was between the $3 \mathrm{rd}$ and 10th centile, and his height was between the 50th and 75th centile. Systemic examination was normal apart from reduced air entry on the right side, mainly the posterior lower zone of the chest. There was no hepatosplenomegaly or bleeding tendency and nor was there neurological or developmental impairment.

A thorough look at the history and examination raises the possibility of the coexistence of other pathology other than the pneumonia, especially that the child remained afebrile despite the worsening chest X-ray (CXR). Therefore, prompt investigations were ordered.

\section{INVESTIGATIONS}

Preliminary investigation revealed anaemia with an elevated acute phase reactant. The relevant haematological findings were haemoglobin of $8.8 \mathrm{~g} \%$, and total white cell count was within the normal range of a healthy population with no leucopenia, neutropenia or lymphopenia. The total leucocyte count was $11900 / \mu \mathrm{L}$ and the platelet count $531000 / \mu$ L. Differential leucocyte counts showed $60 \%$ lymphocytes, $26 \%$ neutrophils, $10 \%$ 
Table 1 CHS 1 mutations

\begin{tabular}{|c|c|c|c|c|c|c|c|}
\hline \multicolumn{4}{|c|}{ 'Childhood' form of the disease } & \multicolumn{4}{|c|}{ Adolescent'or 'Adult' form of the disease } \\
\hline Genotype & $\begin{array}{l}\text { Effect on LYST } \\
\text { mRNA }\end{array}$ & mRNA & Protein & Genotype & $\begin{array}{l}\text { Effect on LYST } \\
\text { mRNA }\end{array}$ & mRNA & Protein \\
\hline Homozygous & $\begin{array}{l}\text { Nonsense/ } \\
\text { frameshift }\end{array}$ & c.1467delG & E489fsX566 & Homozygous & $\begin{array}{l}\text { Nonsense/ } \\
\text { frameshift }\end{array}$ & $c .5784+5 \mathrm{G}>\mathrm{T}$ & $\begin{array}{l}\text { Acceptor splice } \\
\text { site }\end{array}$ \\
\hline Homozygous & $\begin{array}{l}\text { Nonsensel } \\
\text { frameshift }\end{array}$ & c.1899insA & K633fsX638 & Homozygous & Missense & c.5996 T>A & V1999D \\
\hline Homozygous & $\begin{array}{l}\text { Nonsense/ } \\
\text { frameshift }\end{array}$ & c.9590delA & Y3197fsX3258 & Homozygous & Missense & c.9827_9832del6bp & N3276_T3277del \\
\hline Homozygous & $\begin{array}{l}\text { Nonsense/ } \\
\text { frameshift }\end{array}$ & c. $3085 C>T$ & Q1029X & $\begin{array}{l}\text { Compound } \\
\text { heterozygous }\end{array}$ & $\begin{array}{l}\text { Missense } \\
\text { Nonsense/ } \\
\text { frameshift }\end{array}$ & $\begin{array}{l}\text { c. } 10127 \mathrm{~A}>\mathrm{G} \\
\text { c. } 2413 \mathrm{delG}\end{array}$ & $\begin{array}{l}\text { N3376S } \\
\text { E805fsX806 }\end{array}$ \\
\hline Homozygous & $\begin{array}{l}\text { Nonsense/ } \\
\text { frameshift }\end{array}$ & c.2620delT & F874fsX898 & $\begin{array}{l}\text { Compound } \\
\text { heterozygous }\end{array}$ & $\begin{array}{l}\text { Missense } \\
\text { Nonsense/ } \\
\text { frameshift }\end{array}$ & $\begin{array}{l}\text { c. } 8428 \mathrm{G}>\mathrm{A} \\
\text { c. } 4274 \mathrm{delT}\end{array}$ & $\begin{array}{l}\text { E2810K } \\
\text { L1425fsX1426 }\end{array}$ \\
\hline Homozygous & $\begin{array}{l}\text { Nonsense/ } \\
\text { frameshift }\end{array}$ & c.10395delA & K3465fsX3467 & $\begin{array}{l}\text { Compound } \\
\text { heterozygous }\end{array}$ & $\begin{array}{l}\text { Missense } \\
\text { Nonsense/ } \\
\text { frameshift }\end{array}$ & $\begin{array}{l}\text { c. } 4361 C>A \\
\text { c. } 5061 \mathrm{~T}>\mathrm{A}\end{array}$ & $\begin{array}{l}\text { A1454D } \\
\text { Y1687X }\end{array}$ \\
\hline Homozygous & $\begin{array}{l}\text { Nonsense/ } \\
\text { frameshift }\end{array}$ & c.7060-7066del 7 bp & L2354fsX2369 & $\begin{array}{l}\text { Compound } \\
\text { heterozygous }\end{array}$ & $\begin{array}{l}\text { Missense } \\
\text { Nonsense/ } \\
\text { frameshift }\end{array}$ & $\begin{array}{l}\text { c. } 9925 \mathrm{G}>\mathrm{A} \\
\text { c. } 1507 \mathrm{C}>\mathrm{T}\end{array}$ & $\begin{array}{l}\text { G3309S } \\
\text { R503X }\end{array}$ \\
\hline Homozygous & $\begin{array}{l}\text { Nonsense/ } \\
\text { frameshift }\end{array}$ & c.7555delT & Y2519fsX2528 & Heterozygous & $\begin{array}{l}\text { Nonsense/ } \\
\text { frameshift }\end{array}$ & c. $8583 \mathrm{G}>\mathrm{A}$ & W2861X \\
\hline Homozygous & $\begin{array}{l}\text { Nonsense/ } \\
\text { frameshift }\end{array}$ & c. $9106-9161$ del 56 bp & G3036fsX3051 & Heterozygous & $\begin{array}{l}\text { Nonsense/ } \\
\text { frameshift }\end{array}$ & c. $148 \mathrm{C}>\mathrm{T}$ & R50X \\
\hline Homozygous & $\begin{array}{l}\text { Nonsense/ } \\
\text { frameshift }\end{array}$ & c. $6078 \mathrm{C}>\mathrm{A}$ & Y2026X & Heterozygous & $\begin{array}{l}\text { Nonsense/ } \\
\text { frameshift }\end{array}$ & c.3944-3945insC & Q1847fsX1850 \\
\hline Homozygous & $\begin{array}{l}\text { Nonsense/ } \\
\text { frameshift }\end{array}$ & c.5004delA & G1668fsX1717 & Homozygous & $\begin{array}{l}\text { Nonsense/ } \\
\text { frameshift }\end{array}$ & c. $3310 C>T$ & $\mathrm{R} 1104 \mathrm{X}$ \\
\hline Homozygous & $\begin{array}{l}\text { Nonsense/ } \\
\text { frameshift }\end{array}$ & c.5519delC & S1840fsX1842 & Homozygous & $\begin{array}{l}\text { Nonsense/ } \\
\text { frameshift }\end{array}$ & c.575inst & L192FfsX6 \\
\hline Homozygous & $\begin{array}{l}\text { Nonsense/ } \\
\text { frameshift }\end{array}$ & c. $3310 C>T$ & R1104X & Homozygous & $\begin{array}{l}\text { Nonsense/ } \\
\text { frameshift }\end{array}$ & c.575_576insT & L192fsX197 \\
\hline Homozygous & $\begin{array}{l}\text { Nonsense/ } \\
\text { frameshift }\end{array}$ & c. $11102 \mathrm{G}>\mathrm{T}$ & E3668X & Homozygous & $\begin{array}{l}\text { Nonsense/ } \\
\text { frameshift }\end{array}$ & c. $3310 C>T$ & R1104X \\
\hline Homozygous & $\begin{array}{l}\text { Nonsense/ } \\
\text { frameshift }\end{array}$ & c. $5506 \mathrm{C}>\mathrm{T}$ & R1836X & Homozygous & Missense & c. $961 \mathrm{~T}>\mathrm{C}$ & $\mathrm{C} 258 \mathrm{R}$ \\
\hline Homozygous & $\begin{array}{l}\text { Nonsense/ } \\
\text { frameshift }\end{array}$ & c. $7060-1 \mathrm{G}>\mathrm{A}$ & $\begin{array}{l}\text { Acceptor splice } \\
\text { site }\end{array}$ & Homozygous & Missense & c. $4189 \mathrm{~T}>\mathrm{G}$ & F1397V \\
\hline Homozygous & $\begin{array}{l}\text { Nonsense/ } \\
\text { frameshift }\end{array}$ & c.10551_10552del2 & Y3517X & Homozygous & Missense & c. $4688 \mathrm{G}>\mathrm{A}$ & $\mathrm{R} 1563 \mathrm{H}$ \\
\hline Homozygous & $\begin{array}{l}\text { Nonsense/ } \\
\text { frameshift }\end{array}$ & c. $5506 \mathrm{C}>\mathrm{T}$ & R1836X & Homozygous & & & \\
\hline Homozygous & $\begin{array}{l}\text { Nonsense/ } \\
\text { frameshift }\end{array}$ & c.2374_2375delGA & D792fsX797 & & & & \\
\hline Homozygous & $\begin{array}{l}\text { Nonsense/ } \\
\text { frameshift }\end{array}$ & c. $4508 \mathrm{C}>\mathrm{G}$ & S1483X & & & & \\
\hline Homozygous & $\begin{array}{l}\text { Nonsensel } \\
\text { frameshift }\end{array}$ & c. $5506 \mathrm{C}>\mathrm{T}$ & R1836X & & & & \\
\hline Compound & Missense & c. $2570 \mathrm{C}>\mathrm{G}$ & S857C & & & & \\
\hline heterozygous & $\begin{array}{l}\text { Nonsense/ } \\
\text { frameshift }\end{array}$ & c.9930delT & F3310fsX3346 & & & & \\
\hline $\begin{array}{l}\text { Compound } \\
\text { heterozygous }\end{array}$ & $\begin{array}{l}\text { Nonsense/ } \\
\text { frameshift }\end{array}$ & $\begin{array}{l}\text { c.1540C >T } \\
\text { c.9893delT }\end{array}$ & $\begin{array}{l}\text { R514X } \\
\text { F3298fsX3304 }\end{array}$ & & & & \\
\hline $\begin{array}{l}\text { Compound } \\
\text { heterozygous }\end{array}$ & $\begin{array}{l}\text { Nonsense/ } \\
\text { frameshift }\end{array}$ & $\begin{array}{l}\text { c. } 3622 C>T \\
\text { c. } 11002 \mathrm{G}>\mathrm{T}\end{array}$ & $\begin{array}{l}\text { Q1208X } \\
\text { E3668X }\end{array}$ & & & & \\
\hline $\begin{array}{l}\text { Compound } \\
\text { heterozygous }\end{array}$ & $\begin{array}{l}\text { Nonsense/ } \\
\text { frameshift }\end{array}$ & $\begin{array}{l}\text { c.10445insCA } \\
\text { Not specified }\end{array}$ & $\begin{array}{l}\text { V3483fsX3516 } \\
\text { R2403X }\end{array}$ & & & & \\
\hline Heterozygous & $\begin{array}{l}\text { Nonsense/ } \\
\text { frameshift }\end{array}$ & c.5317delA & R1773fsX1785 & & & & \\
\hline Heterozygous & $\begin{array}{l}\text { Nonsensel } \\
\text { frameshift }\end{array}$ & c.9228ins 10 bp & K3077fsX3080 & & & & \\
\hline Heterozygous & $\begin{array}{l}\text { Nonsense/ } \\
\text { frameshift }\end{array}$ & c.118insG & A40fsX63 & & & & \\
\hline Heterozygous & $\begin{array}{l}\text { Nonsense/ } \\
\text { frameshift }\end{array}$ & c. $3073+3074$ delA & N1025fsX1030 & & & & \\
\hline
\end{tabular}


Table 1 Continued

\begin{tabular}{|c|c|c|c|c|c|c|c|}
\hline \multicolumn{4}{|c|}{ 'Childhood' form of the disease } & \multicolumn{4}{|c|}{ Adolescent'or 'Adult' form of the disease } \\
\hline Genotype & $\begin{array}{l}\text { Effect on LYST } \\
\text { mRNA }\end{array}$ & mRNA & Protein & Genotype & $\begin{array}{l}\text { Effect on LYST } \\
\text { mRNA }\end{array}$ & mRNA & Protein \\
\hline Heterozygous & $\begin{array}{l}\text { Nonsense/ } \\
\text { frameshift }\end{array}$ & c.2454delA & K818fsX823 & & & & \\
\hline Heterozygous & $\begin{array}{l}\text { Nonsense/ } \\
\text { frameshift }\end{array}$ & c.3434-3435insA & $\mathrm{H} 1145 \mathrm{fs} X 1153$ & & & & \\
\hline Heterozygous & $\begin{array}{l}\text { Nonsense/ } \\
\text { frameshift }\end{array}$ & c. $4052 C>G$ & S1351X & & & & \\
\hline Heterozygous & $\begin{array}{l}\text { Nonsense/ } \\
\text { frameshift }\end{array}$ & c.3944-3945insC & $\mathrm{T} 1315 \mathrm{fs} X 1331$ & & & & \\
\hline $\begin{array}{l}\text { Compound } \\
\text { heterozygous }\end{array}$ & $\begin{array}{l}\text { Nonsense/ } \\
\text { frameshift }\end{array}$ & $\begin{array}{l}\text { c. } 7060-1 \mathrm{G}>\mathrm{T} \\
\text { c. } 11196-1 \mathrm{G}>\mathrm{A}\end{array}$ & $\begin{array}{l}\text { Acceptor splice } \\
\text { sites }\end{array}$ & & & & \\
\hline Homozygous & Missense & c. $11362 \mathrm{G}>\mathrm{A}$ & G3725R & & & & \\
\hline Homozygous & $\begin{array}{l}\text { Nonsense/ } \\
\text { frameshift }\end{array}$ & c. $925 \mathrm{C}>\mathrm{T}$ & R309X & & & & \\
\hline Homozygous $^{5}$ & Frameshift & c.5034_5038delTTGGT & p.G1679TfsX19 & & & & \\
\hline
\end{tabular}

monocytes and eosinophils 4\%. C reactive protein: $12 \mathrm{mg} / \mathrm{L}$. Serum ferritin: $14.1 \mathrm{ng} / \mathrm{mL}$ (N: 9.29-58.7).

T-Spot Tuberculosis test: non-reactive. Acid-fast bacilli (AFB) Smear only: AFB not seen. AFB culture and sensitivity (gastric aspirate): not seen.

CXR showed right middle lobe consolidation. Repeated chest X-ray after 1 week revealed patchy opacities, noted in the right lung and left lower lobe, suggestive of progressive pneumonic consolidation.

Immune status screen showed a non-specific reactive picture: CD4,8 RATIO 1.729\% (normal range (N) 1.20-2.40), TOTAL $\mathrm{T}$ CELLS 67.7\% (N:62.0-72.0), CD3 ABS 6119.0 CELL/ $\mu \mathrm{L}$ (N:812-2318), CD4\% 37.7\% (N:35.0-55.0), CD4 ABS 3408.0 CELL/ $\mu \mathrm{L}(\mathrm{N}: 589-1505)$

CD8\% 21.8\% (N:16.0-28.0), CD8 ABS 1971.0 CELL/ $\mu \mathrm{L}$ (N:325-995), CD56\% 2.3\% (N:5.00-13.0), CD56 ABS 208.0 CELL/ $\mu \mathrm{L}$ (N:78-602, CD19\% 21.6\% (N:12.0-28.0)

CD19 ABS 1952.0 CELL/ $\mu L$ (N: 99-426).

Immunoglobulins assay showed elevated immunoglobulin E (IgE) 2680.0 KU/L (N: 0-64), IGG 21.80 g/L (N: 4.07-10.09), IGA $2.01 \mathrm{~g} / \mathrm{L}$ (N: 0.14-1.22), IGM $1.94 \mathrm{~g} / \mathrm{L}$ (N:0.46-1.60).

Liver and renal function tests were normal.

The characteristic feature in the peripheral blood film was the existence of several abnormal large granules in the cytoplasm of neutrophils and eosinophilis (figure 2A). A large round to oval azurophilic cytoplasmic granule in a few lymphocytes was observed. Platelets show mild reactive thrombocytosis. WBCs morphology is highly suggestive of the CHS.

Genetic study (CHS1 gene) (figure 3) was performed by the following method: the coding regions and intronic flanking regions ( \pm 8 bp) of the LYST gene (NM_000081.3; chr.1) were completely sequenced in this test. The test is performed by oligonucleotide-based target capture (QXT, Agilent Technologies) followed by next generation sequencing (MiSeq, Illumina). Alignment and variant calls were generated using the Burrows-Wheeler Aligner (BWA, MiSeq reporter) followed by Next GENe (Soft Genetics) analysis. Where necessary, Sanger sequencing was used to provide data for bases with insufficient coverage (mean coverage under $100 \times$ and/or minimum coverage of $<20 \times$ ). Independent Sanger sequencing confirmed all clinically significant and novel variants.

\section{DIFFERENTIAL DIAGNOSIS}

- The presence of right lobe pneumonia with loss of weight according to the mother in addition to the history of exposure to house cleaner with old tuberculosis, made tuberculosis a possible diagnosis, which did not show by the negative tuberculin and negative T-spot test. No acid-fast bacilli (AFB) were isolated after 57 days in the gastric aspirate culture.

- The presence of hypopigmentation and hyperpigmentation with skin eczema raised the possibility of xeroderma pigmentosa where the child develops freckling of the skin exposed to sun, especially the face, arms and lips. On the other hand, the child's skin colour was medium fair with areas of hyperpigmentation on the forehead and hypopigmentated macules, behind the ear on the chest wall, at the scapular area and dorsum at the hand and foot.

- The possibility of immune deficiency was considered, especially that the child remained afebrile with worsening of the CXR and presence of Pseudomonas aeuroginosa in the sputum culture. This organism has become an important cause of infection in the immunocompromised host. Immune status and immunoglobulins assay as well as B and T lymphocytes function were all normal.

- The differentials of CHS, namely Griscelli syndrome type 2 and Hermansky-Pudlak syndrome type 2, were excluded by the presence of abnormal azurophilic granules in neutrophilis, eosinophilis and lymphocytes, which is a hallmark of CHS.

\section{TREATMENT}

The child was started on empirical antibiotics until results of sputum culture, which showed Haemophilus influenza and $P$. aeruginosa. Therefore, the child was treated accordingly. Follow-up CXR showed new infiltration on the left side, so another antibiotic was added.

\section{OUTCOME AND FOLLOW-UP}

The child remained stable, repeated CXR showed possible cavity on the right lower lobe; the child was advised for chest CT scan but his father disagreed. The child was discharged prematurely against medical advice. Parents were instructed about the important measures to prevent routine infections including 

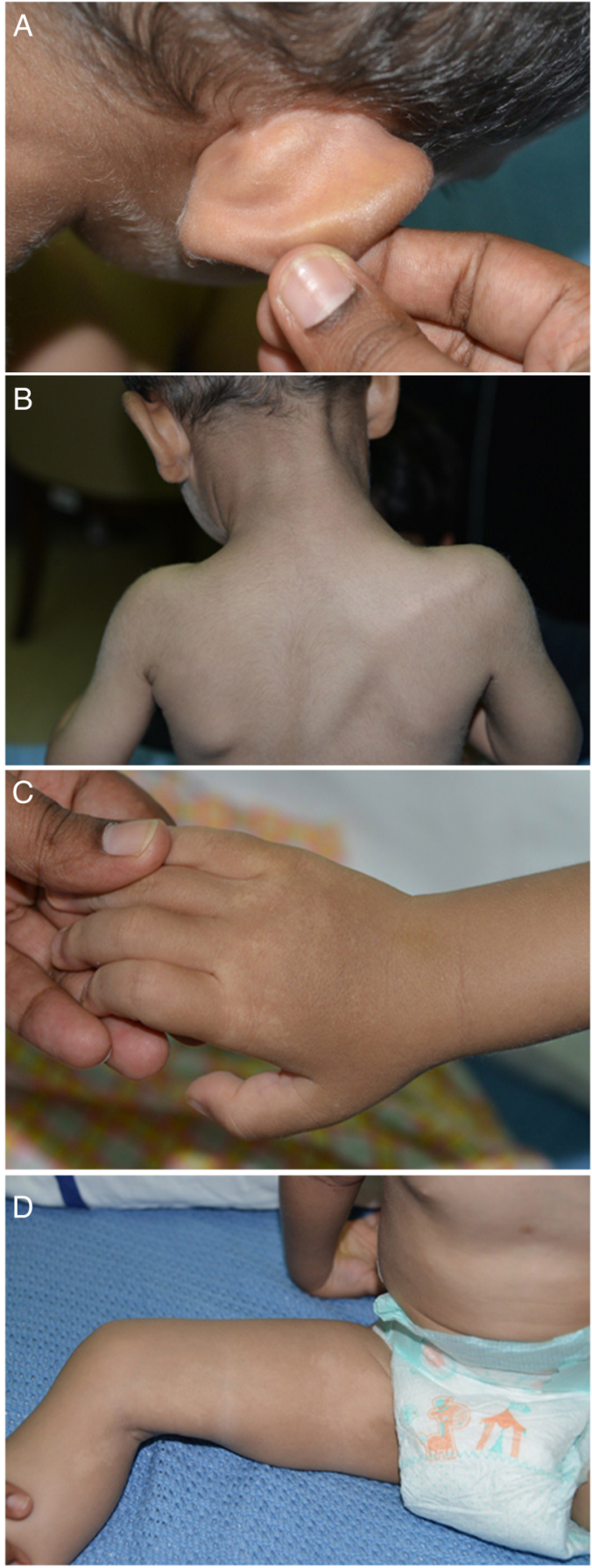

Figure 1 Hypopigmentation and hyperpigmentation at the back of the ear and nape of the neck with hair colour changes (grey). (B): hypopigmentation of the skin at the back. (C): hypopigmentation patches at the dorsum of the hand. (D): hypopigmentation at the inner thigh.

meticulous attention to oral and dental care, and skin protection and sunglasses to prevent sunburn.

On receiving the report of gene testing, the parents were advised to go for further management considering the need for bone marrow transplantation. Genetic counselling for patient/ parents and at-risk relatives was also recommended.

Human leucocyte antigen (HLA) testing was performed for the parents and siblings for possible bone marrow transplantation; unfortunately, HLA testing for parents and siblings showed four mismatches with the patient.

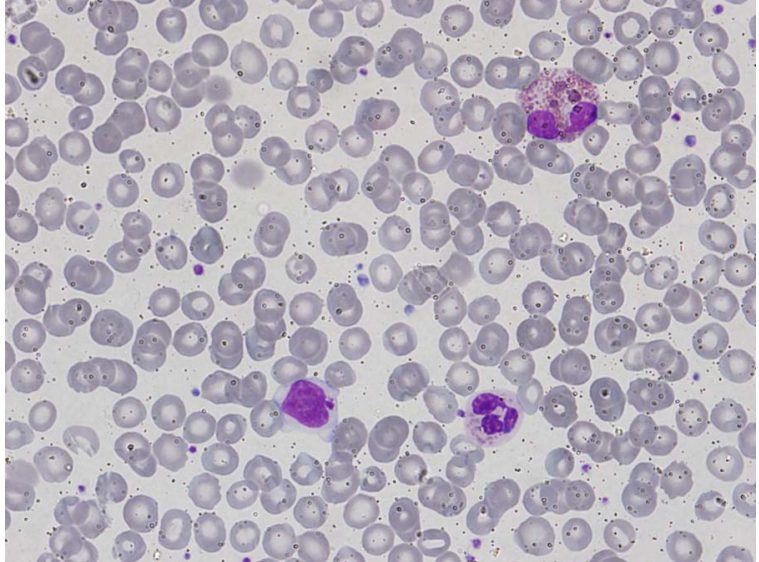

Figure 2 (A) A neutrophil and eosinophil showing giant granules and a lymphocyte with a single large azurophilic granule ((Leishman's stain, 100x).

\section{DISCUSSION}

The Chediak-Higashi syndrome is a disease of infancy and early childhood. CHS is a rare autosomal recessive disorder characterised by oculocutaneous albinism of variable degrees, recurrent pyogenic infections, a tendency for mild bleeding and neurological dysfunction which appears later in life.

Our patient presented with pneumonia. An interesting aspect of our patient was the absence of recurrent infections or any other clinical stigmata apart from eczema and anaemia. Still, it is early to classify our patient regarding CHS forms. His manifestations did not fit in the classic (accelerated phase) form yet; in particular, he suffered only two episodes of infection throughout his life, but he might develop this phase at any time in his life. Although most children with CHS will present with a primary history of recurrent infections for a variable period of time before entering the accelerated phase, some authors reported the accelerated phase as the primary presentation. ${ }^{7}$ On the other hand, the mild form might be considered which only contributes to $10-15 \%$ of CHS . Children presenting with the mild form have subtle hypopigmentation, less infections and frequent mild bleeding manifestations. Nonetheless, during adolescence or adulthood, they develop progressive neurological symptoms. ${ }^{6}$ Our patient cannot be considered as having partial albinism, because he had scattered areas of hypopigmentation and hyperpigmentation. Fukai et $a l,{ }^{8}$ had previously reported a case of CHS with hyperpigmentation on the face. This finding could be attributed to failure of degradation of melanosomes or melanosome complexes. Moreover, this finding might be due to the constitutional increase in tyrosinase activity in the dark skin population, which leads to increased pigmentation of exposed areas. ${ }^{5}$ On the other hand, our patient and his parents and siblings were not of the dark skin population.

The most striking abnormality in our case was the presence of azurophilic granules in neutrophils, eosinophils and lymphocytes in blood film, which is a characteristic of CHS. On the other hand, peripheral blood examination for both parents and siblings revealed no similar granules.

The genetic defect that results in CHS was recorded in $1996,{ }^{2} 3$ and mapped to human chromosome 1q42-44.

The gene which includes 53 exons (51 coding) with a reading open frame of $11406 \mathrm{bp}$ and encodes for a 3801 amino acid protein is CHS1 (LYST, OMIM number 606897). This is a 

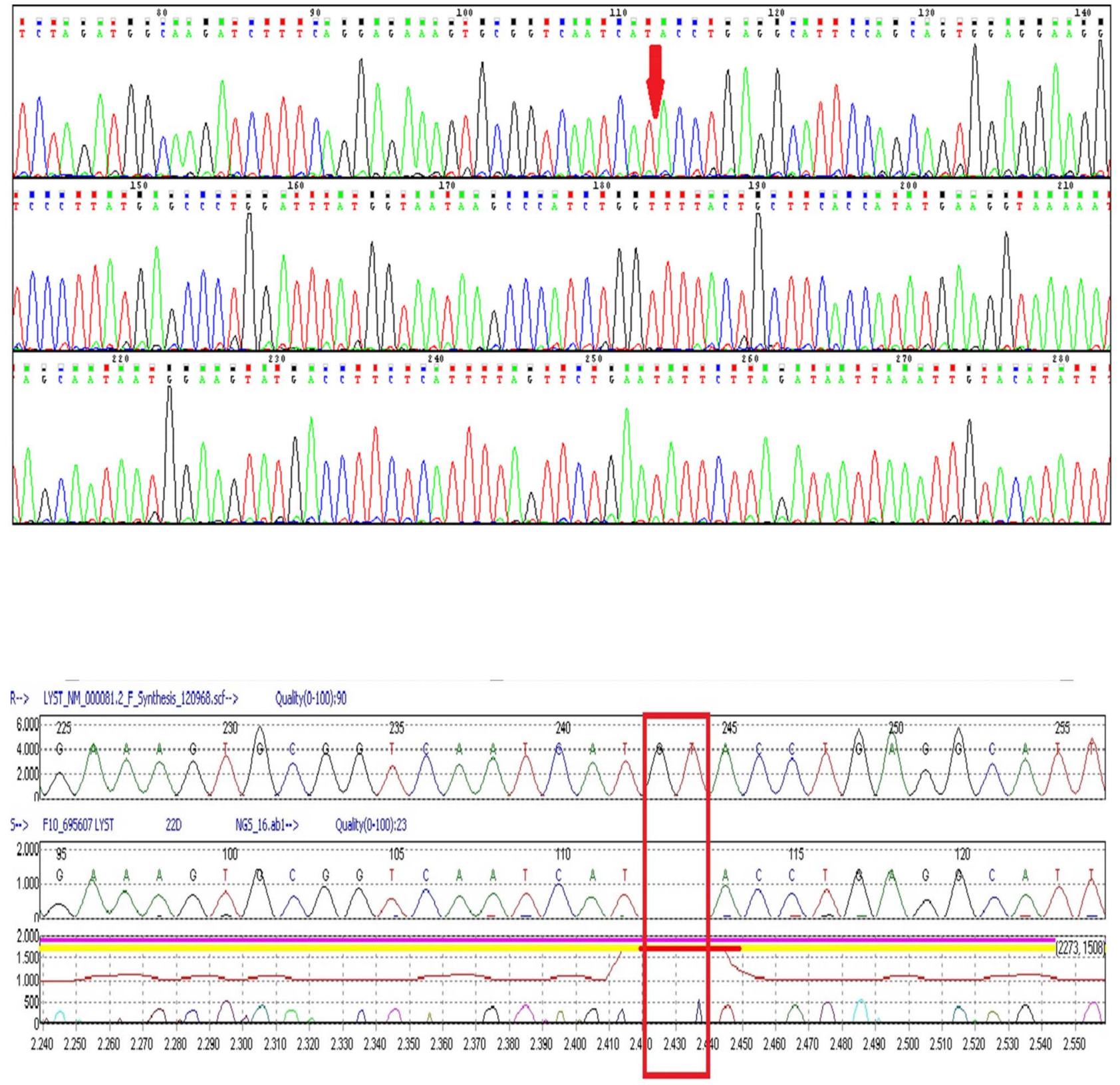

Figure 3 Electropherogram of the LYST novel gene mutation.

highly conserved, large cytosolic protein of $\sim 430 \mathrm{kDa}$. Several ARM/HEAT $\alpha$-helix repeats of $\mathrm{N}$-terminal extreme are followed by a BEACH domain and a C-terminal domain of seven WD40 repeats. Until now, the CHS1 gene exact function is still unknown. It is anticipated to have a role in regulating the size, fission and secretion of the lysosome-related organelle. ${ }^{9}$

Molecular diagnosis is challenging and cumbersome because of the sheer size of the gene. In our case, the genetic (CHS1 gene) testing revealed an apparently homozygous c.6159_6160 del (p.Met2053Ilefs*31) variant in the LYST gene. This is a novel variant genotype of CHS, which was not reported in any literature until now. This a novel variant not previously described in the literature. However, since it is predicted to create a premature stop codon (p.Met2053Ilefs*31) and therefore to produce a truncated LYST protein, it is most likely a disease-causing mutation. This result confirms the clinical diagnosis of the CHS caused by mutations in the CHS1gene.

Clinical CHS phenotypes correlate with molecular genotypes. Patients with CHS with deletions in the CHS1 gene usually present with a fulminant accelerated phase early in life, whereas those with missense mutations have a better prognosis, characterised by the absence of an accelerated phase and no neurological involvement. ${ }^{10}$ Our patient presented with a mild form of the disease.

It is critical to identify patients who present with this disease to enrol them into transplantation protocol, which is the only curative treatment.

Genetic counselling for patient/parents and at-risk relatives was recommended. Parents and siblings were subjected to HLA testing for possible bone marrow transplantation. 


\section{Learning points}

- The Chediak-Higashi syndrome is a rare, most likely under-diagnosed, autosomal recessive disorder that should be suspected in a child who has partial albinism and a history of recurrent or severe infections. The majority of cases have the classic form of the disease, which is universally fatal without allogeneic transplantation. The disorder can be easily screened for, with a careful examination of a peripheral blood smear showing giant granules in neutrophils and to be confirmed by genetic testing.

- The physicians should be alert to recognise signs pointing to the coexistence of a rare but serious life-threatening systemic disease.

- Identification of the mutation type will facilitate timely diagnosis, management and family counselling for those with affected children.

- We emphasise the need for early diagnosis of such conditions, based on clinical characteristics as well as diagnostic laboratory examinations, which leads to early transplantation before development of the accelerated phase.

Contributors MS designed and wrote the manuscript, provided the pictures, and was involved in the management of the child. BY helped in the writing of the manuscript, and was involved in the management of the child. MMH supervised the management of the child and revised the manuscript. DE provided the pictures and revised the manuscript and was involved in the diagnosis of the child.

Competing interests None declared.

\section{Patient consent Obtained.}

Provenance and peer review Not commissioned; externally peer reviewed.

\section{REFERENCES}

1 Kaplan J, De Domenico I, Ward DM. Chediak-Higashi syndrome. Curr Opin Hematol 2008;15:22-9.

2 Barbosa MD, Nguyen QA, Tchernev VT, et al. Identification of the homologous beige and Chediak-Higashi syndrome genes. Nature 1996;382:262-5.

3 Nagle DL, Karim MA, Woolf EA, et al. Identification and mutation analysis of the complete gene for Chediak-Higashi syndrome. Nat Genet 1996;14:307-11.

4 Janka GE. Familial and acquired hemophagocytic lymphohistiocytosis. Eur J Pediatr 2007;166:95-109.

5 Singh A, Bryan MM, Roney JC, et al. A clinical report of Chediak-Higashi syndrome in infancy with a novel genotype from the Indian subcontinent. Int J Dermatol 2015;55:317-21.

6 Lozano ML, Rivera J, Sánchez-Guiu IS, et al. Towards the targeted management of Chediak-Higashi syndrome. Orphanet J Rare dis 2014;9:132.

7 Nargund AR, Madhumathi DS, Premalatha CS, et al. Accelerated phase of Chediak-Higashi syndrome mimicking lymphoma-a case report. J Pediatr Hematol Oncol 2010;32:e223-6.

8 Fukai $\mathrm{K}$, Ishii M, Kadoya A, et al. Chediak-Higashi syndrome: report of a case and review of the Japanese literature. J Dermatol 1993;20:231-7.

9 Durchfort N, Verhoef S, Vaughn MB, et al. The enlarged lysosomes in beige j cells result from decreased lysosome fission and not increased lysosome fusion. Traffic 2012;13:108-19

10 Westbroek W, Adams D, Huizing M, et al. Cellular defects in Chediak-Higashi syndrome correlate with the molecular genotype and clinical phenotype. Invest Dermatol 2007;127:2674-7.

Copyright 2017 BMJ Publishing Group. All rights reserved. For permission to reuse any of this content visit http://group.bmj.com/group/rights-licensing/permissions.

BMJ Case Report Fellows may re-use this article for personal use and teaching without any further permission.

Become a Fellow of BMJ Case Reports today and you can:

- Submit as many cases as you like

- Enjoy fast sympathetic peer review and rapid publication of accepted articles

- Access all the published articles

- Re-use any of the published material for personal use and teaching without further permission

For information on Institutional Fellowships contact consortiasales@bmjgroup.com

Visit casereports.bmj.com for more articles like this and to become a Fellow 